\title{
Analisis Lemak Babi Pada Bakso Menggunakan Spektrofotometer Fourier Transform Infrared (FTIR)
}

\author{
Millen Nur Islami ${ }^{1 *}$, Raden Fatahillah ${ }^{2}$, Selpi Suriana ${ }^{3}$, Ambar Wati $^{4,}$ Syafiana Khusna Aini ${ }^{5}$ \\ 1,2,3,4 Jurusan Kimia, Fakultas Sains dan Teknologi, Universitas Islam Negeri Raden Fatah Palembang \\ ${ }^{5}$ Balai Besar POM Semarang \\ *nurislamimillen@gmail.com
}

\begin{abstract}
ABSTRAK
Indonesia merupakan negara dengan mayoritas penduduknya beragama Islam, sehingga adanya produk makanan yang tercampur dengan bahan non-halal dapat menjadi masalah baru di masyarakat. Pada saat ini harga daging sapi relatif mahal dipasaran sehingga pencampuran daging sapi dengan daging babi dalam pembuatan bakso merupakan solusi efektif yang dapat menurunkan harga produksinya. Metode penelitian ini meliputi proses ekstraksi sokletasi dan analisis kandungan lemak babi menggunakan metode spektroskopi FTIR. Studi penggunaan spektrofotometri Fourier Transform Inframerah (FTIR) dapat digunakan untuk mengidentifikasi adanya daging babi hutan pada bakso sapi secara kualitatif. Hasil pengujian terhadap sampel bakso asal pedagang kaki lima di pasar 15 Ulu Palembang menunjukkan bahwa tidak ada pemalsuan daging babi pada sampel bakso tersebut.
\end{abstract}

Kata kunci : Bakso sapi; Daging babi hutan; Produk non halal; Spektroskopi FTIR

\begin{abstract}
Indonesia is a country with a majority Muslim population, so the presence of food products mixed with non-halal ingredients can be a new problem in society. At this time the price of beef is relatively expensive in the market so that mixing beef with pork in making meatballs is an effective solution that can reduce production prices. This research method includes the process of socletation extraction and then analyzing the content of lard using the FTIR spectroscopy method. The study of Fourier Transform Infrared (FTIR) spectrophotometry can be used to identify the presence of wild boar meat in beef meatballs qualitatively. The results of tests on meatball samples from street vendors in the 15 Ulu Palembang market showed that there was no counterfeiting of pork in the meatball samples.
\end{abstract}

Keyword : Beef meatballs; FTIR spectroscopy; Non-halal produk; Pork

\section{PENDAHULUAN}

Indonesia merupakan negara yang mayoritasnya pemeluk agama islam sehingga isu mengenai pemalsuan kehalalan produk makanan menjadi masalah baru yang beredar di masyarakat, seperti adanya bahan baku non-halal dalam produk makanan tersebut (Hilda, 2014).
Salah satu syarat produk dikatakan halal dzatnya yaitu tidak mengandung unsur babi ataupun turunannya, baik itu lemak maupun daging nya. Allah SWT berfirman dalam Al-Qur'an Surat Al-Baqarah: 173, tentang larangan penggunaan unsur babi yang artinya : "Sesungguhnya Allah hanya mengharamkan bagimu bangkai, darah, 
babi, dan binatang yang (ketika disembelih) disebut (nama) selain Allah. Tetapi barang siapa dalam keadaan terpaksa, sedang ia tidak menginginkannya dan tidak melampaui batas, maka tidak ada dosa baginya. Sesungguhnya Allah maha pengampun dan penyayang. (Q.S. AlBaqarah :173). Didalam ayat tersebut telah dicantumkan dengan jelas bahwa daging babi tidak boleh dikonsumsi oleh seseorang yang beragama Islam.

Adapun didalam Al-Qur'an surah Al-Maidah ayat 88 umat islam diwajibkan mengkonsumsi makanan yang halal yang artinya "Makanlah makanan yang halal lagi baik", untuk memastikan apakah produk pangan tersebut apakah halal atau tidak, maka produk pangan dapat diwujudkan dengan pemberian sertifikasi halal dengan mencantumkan logo halal pada kemasannya (Sayekti, 2014).

Bakso adalah makanan yang menjadi salah satu makanan favorit di Indonesia. Pembuatan bakso biasanya dibuat dari daging sapi dan bumbu-bumbu sesuai yang diperlukan. Pada saat ini harga produksi daging sapi dipasaran relatif mahal sehingga para pedagang sering melakukan kecurangan dengan mencampur produk daging sapi dengan daging hutan untuk meminimalkan harga produksi bakso olahan (Guantarti, 2017).

Lemak babi merupakan bahan baku makanan yang sering dimanfaatkan masyarakat untuk menambah cita rasa produk olahan makanan serta harganya yang relatif murah di pasaran, sehingga banyak pedagang yang memanfaatkan daging babi untuk dicampurkan kedalam produk makanan halal (Taufik, 2018).

Adanya kandungan lemak babi dapat diketahui menggunakan alat spektrofotometri FTIR. Adapun FTIR merupakan instrumen yang dapat menganalisis dan memprediksi unsur atau senyawa yang terdapat dalam suatu produk. Dengan demikian, metode ini baik digunakan untuk menganalisis kehalalan suatu produk dengan cara melihat adanya kandungan lemak babi dalam suatu produk makanan (Sulistyani, 2017).

Namun demikian, salah satu kekurangan dari spektrofotometri ini adalah adanya gugus $\mathrm{CO}_{2}$ dan air di udara yang dapat terbaca pada spektrum sehingga dapat terjadi kemungkinan kesalahan pada spektrum ftir ini (Hasanah, 2015).

Pada penelitian ini akan dianalisa kandungan lemak babi pada sampel bakso asal pedagang kaki lima di pasar 15 Ulu Palembang dengan instrument FTIR.

\section{METODOLOGI PENELITIAN}

\section{Alat dan Bahan}

Alat - alat yang digunakan dalam penelitian ini adalah Gelas Ukur, Pipet Tetes, Soxhlet, Termometer, Blender, Oven, Botol Reagen, Gelas Kimia, Hot Plate, Neraca Analitik, Spatula, Cawan Petri, Pengaduk, Statif, klem dan Spektrofotometer IR.

Bahan - bahan yang digunakan dalam penelitian ini adalah produk olahan bakso yang didapatkan di salah satu pasar 15 Ulu Palembang, Minyak Goreng, Kloroform p.a dari Merck, Kertas Saring, Aluminium, dan Plastik Wrap.

\section{Prosedur}

Sampel dihaluskan menggunakan blender dan dikeringkan menggunakan oven selama 2 jam pada suhu $100^{\circ} \mathrm{c}$. Sebanyak 60 gram sampel bakso diekstraksi menggunakan alat soxhlet dengan menggunakan pelarut kloroform $100 \mathrm{ml}$ selama 2,5 jam. Ekstrak campuran yang dihasilkan diuapkan selama 24 jam dan kemudian dianalisis ekstrak lemak murni dengan menggunakan spektroskopi FTIR.

Ekstraksi lemak pada penelitian ini menggunakan alat Soxhlet (Gambar 1) dengan pelarut kloroform yang diharapkan mampu mengektraksi seluruh lemak yang berada didalam adonan produk olahan bakso. 


\section{HASIL DAN PEMBAHASAN}

\section{a. Ekstraksi Lemak Babi}

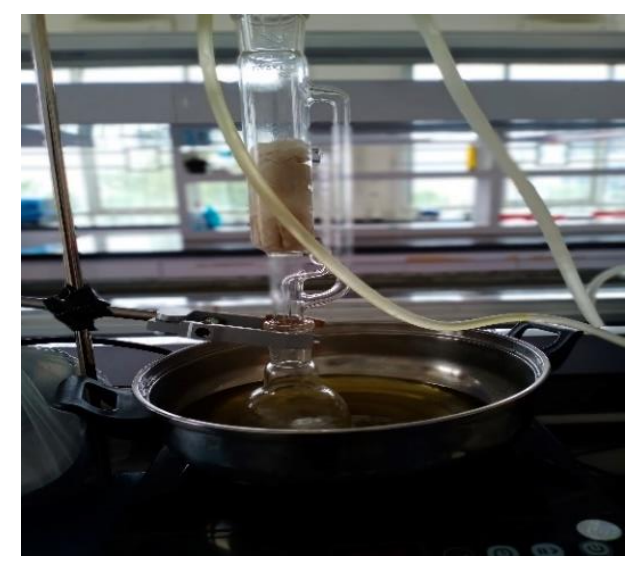

Gambar 1. Proses ekstraksi lemak menggunakan alat soxhlet

Adapun ekstraksi soxhlet adalah proses ekstraksi padat cair dengan tujuan mengambil suatu senyawa penting dalam sampel menggunakan pelarut organik (Melwita, 2014).

Proses ekstraksi ini dilakukan menggunakan pelarut klorofom. Hal ini dikarenakan pelarut kloroform cocok digunakan dalam ekstraksi lemak pada produk olahan bakso, karena sifatnya yang non polar sama seperti lemak yang juga bersifat non polar serta pelarut kloroform ini mudah menguap dibandingkan pelarut organik lain. Penguapan pelarut kloroform yang terdapat di dalam ekstrak lemak dilakukan di dalam lemari asam dalam waktu \pm 24 jam.

\section{b. Analisis Lemak dengan Spektrofotometri FTIR}

Setelah didapatkan hasil ekstraksi, selanjutnya ekstrak lemak dianalisis menggunakan instrumen FTIR. Adapun FTIR merupakan suatu teknik analisis yang digunakan untuk dimanfaatkan dalam analisa dalam berbagai produk, seperti produk pangan dikarenakan suatu analisanya yang relatif akurat dan cepat serta minimnya kesalahan dalam spektra yang dihasilkan (Herianto, 2016).
Menurut Banu (2014), lemak babi mengandung lebih banyak asam lemak tak jenuh seperti linoleat dan linolenat dibandingkan dengan lemak sapi. Adapun ciri- ciri dari asam lemak tak jenuh yaitu memiliki ikatan rangkap pada karbonnya. Menurut Vacawati (2013), lemak babi dan lemak ayam memiliki pola struktur yang hampir mirip, namun terdapat perbedaan pada puncak gelombangnya, yang mana lemak babi memiliki puncak gelombang yang relatif lebih tinggi dibandingkan lemak ayam di beberapa panjang gelombang tertentu. Hal ini sejalan dengan penelitian Irwandi (2003), dimana tingginya puncak serapan menunjukkan adanya ikatan rangkap $\mathrm{C}=\mathrm{C}$ yang mengindikasikan adanya lemak tak jenuh dalam sampel tersebut. Adapun perbedaan hasil spektra untuk lemak babi biasanya terdapat overlaping atau tumpang tindih dari dua puncak serapan pada bilangan gelombang antara $1118-1098 \mathrm{~cm}^{-1}$, sedangkan untuk lemak ayam atau lemak sapi tidak menunjukkan adanya overlaping pada puncak serapan dalam spektra yang dihasilkan (Hermanto, 2008).

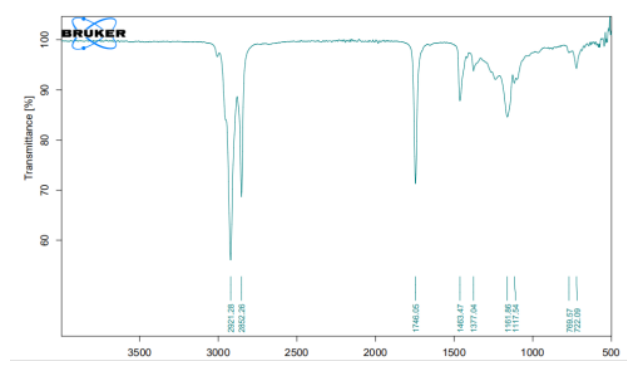

\section{Gambar 2. Hasil spektra IR Analisis ekstrak lemak dengan spektroskopi FTIR}

Pada gambar 2 terlihat bahwa spektra FTIR dari sampel lemak secara umum menunjukan adanya serapan $(\mathrm{C}-\mathrm{O})$ di daerah bilangan gelombang 1000-1300 $\mathrm{cm}^{-1}$, Vibrasi tekukan $\mathrm{O}-\mathrm{H}$ pada daerah 1300-1440, Ikatan karbonil $(\mathrm{C}=\mathrm{O})$ pada daerah 1680-1750 $\mathrm{cm}^{-1}$, dan ikatan $\mathrm{C}-\mathrm{H}$ pada daerah antara $2853-2962 \mathrm{~cm}^{-1}$.

Hasil analisis spektra pada gambar 2 tidak menunjukkan adanya kandungan 
lemak babi. Hal ini terlihat dari puncak serapan yang tidak terlalu tinggi bila dibandingkan dengan puncak serapan gelombang yang dimiliki oleh lemak babi serta tidak menunjukkan adanya ikatan rangkap karbon yang mengidentifikasi adanya asam lemak tak jenuh yang merupakan karakteristik lemak babi dari hasil analisis spektra tersebut. Selain itu, hasil spektra yang dihasilkan tidak menunjukkan adanya tumpang tindih antara dua daerah bilangan gelombang sehingga hasil analisis mengindikasikan bahwa sampel produk olahan bakso ini tidak mengandung lemak babi.

\section{KESIMPULAN}

Sampel bakso pada penelitian ini menunjukkan hasil negatif terhadap lemak daging babi yang dibuktikan dengan tidak adanya ikatan rangkap $\mathrm{C}=\mathrm{C}$ pada sampel, yang berarti lemak yang terdapat pada sampel adalah asam lemak jenuh.

\section{DAFTAR PUSTAKA}

Banu Adi Permana. 2014. Penelusuran Deteksi Lemak Babi dalam Campuran Lemak dengan FTIR. Skripsi. Bogor: Institut Pertanian Bogor.

Guantarti, Any dkk. 2017. "Aplikasi metode Fourier Transform Infrared (FT-IR) dikombinasikan dengan kemometrika untuk analisis daging tikus rumah dalam bakso daging sapi”. Jurnal Homepage. 7(2) : 2

Hasanah, A. 2015. Karakterisasi Asam Lemak Sapi dan Asam Lemak Babi Secara Voltametri Siklik. Yogyakarta : Universitas Islam Negeri Sunan Kalijaga

Herianto, Rudi dan dkk. 2016. "Karakteristik Karbon Aktif asal tumbuhan dan tulang hewan menggunakan FTIR dan analisis kemometrika". Jurnal Kimia Valensi. 1(2) : 1

Hermanto, dkk. 2008. Profil dan Karakterisasi Asam Lemak Sapi dan Asam Lemak Babi Secara Voltametri Siklik. Yogyakarta : UIN Syarif Hidayatullah

Hilda, Lelya. 2014. "Analisis kandungan lemak babi dalam produk pangan di padangsimpuan secara kualitatif dengan menggunakan GC". Takdir. $2(9): 2$

Irwandi J, dkk. 2003. "Determination of Lard in Mixture of body fats of Mutton and Cow by Fourier Transform Infrared Spectroscopy". Journal Oleo Sci. 52 (12) : 633

Melwita, Elda dkk. 2014. "Ekstraksi Minyak Biji Kapuk dengan Metode Ekstraksi Soxhlet". Teknik Kimia. $1(20): 23$

Sayekti, Nidya Waras. 2014. "Jaminan Produk Halal dalam Perspektif Kelembagaan". Jurnal Ekonomic Kebijakan Publik. 2(5) : 193 - 209

Sulistiyani, Martin dan Nuril Huda. 2017. "Optimasi Pengukuran Spektrum Vibrasi Sampel Protein Menggunakan Spektrofotometer Fourier Transform Infrared (FTIR)". Indonesian Journal of Chemical Science. 6(2):174

Taufik, M, dkk. 2018. “Analisis Sifat Fisika Lemak Babi Hasil Ekstraksi Pada Produk Pangan Olahan". Jurnal Teknologi Pangan dan Hasil Pertanian". 1(2) : 79

Vacawati, W.D.,dkk. 2013. Deteksi Lemak Babi dan Lemak Ayam Menggunakan FTIR (Fourier Transform Infrared) dan Kemometrik sebagai Verifikasi Halal. Jember : Universitas Jember. 